\title{
Normal and Variant Anatomy of Renal Hilar Structures and its Clinical Significance
}

\author{
Anatomía Normal y Variante de las Estructuras Hiliares Renales y su Significancia Clínica
}

Trivedi, S.; Athavale, S. \& Kotgiriwar, S.

TRIVEDI, S.; ATHAVALE, S. \& KOTGIRIWAR, S. Normal and variant anatomy of renal hilar structures and its clinical significance. Int. J. Morphol., 29(4):1379-1383, 2011.

SUMMARY: Advanced imaging techniques have resulted in increasing use of minimally invasive approaches for nephron sparing surgeries of kidney. Need for precise knowledge of normal and variant anatomy of vascular pedicle of kidney is thus justified. Ample literature is available on the variations in the intrarenal vascular pattern of the kidney, which are seen frequently. But the variation in arrangement of structures at the renal hilum has not gained much interest up till now. One hundred (51 right and 49 left) embalmed kidneys were utilized for the present study. Careful dissection of renal hilar structures was carried out to observe antero-posterior relationship of structures at the hilum of the kidney. In majority (73\%), the arrangement was not according to the normal textbook description i.e. renal vein, renal artery and pelvis arranged antero-posteriorly. In $31 \%$ anterior division of renal artery was seen in front of renal vein at the hilum, whereas, in $50 \%$ cases the pelvis was not the posterior most relation. The variable patterns observed were classified into five types. In cases of renal hilar tumors laparoscopic partial nephrectomy is being done with a limited field of vision. Knowledge of these variations is useful for operating surgeons to identify and individually clamp the hilar structures, which is advantageous over en-bloc clamping.

KEYWORDS: Kidney; Laparoscopic partial nephrectomy; Renal hilum; Variations.

\section{INTRODUCTION}

Kidney tumors are being increasingly detected at smaller sizes, subsequent to advancement in imaging techniques, when they are potentially amenable to nephron sparing surgery (Nuygen et al., 2006). Radical nephrectomies pose a risk for deterioration of renal function, associated with cardiovascular morbidity, hospitalization and death (Huang et al., 2006). In such cases partial nephrectomy is taking precedence over radical nephrectomy. Laparoscopic partial nephrectomy (LPN) has demonstrated benefits compared to open partial nephrectomy (Rogers et al., 2008). LPN is technically challenging because of limited field of vision and the need for hilar dissection for vascular clamping (Desai \& Gill, 2005). Clamping of individual structures at the hilum is preferred rather than en-bloc clamping (Rapp et al., 2004). Knowledge of structures at the renal hilum is thus necessary prior to any surgical intervention of the kidney.

The arrangement of structures at the renal hilum, antero-poteriorly as described in standard anatomical texts is: renal vein, renal artery and pelvis. Posterior division of renal artery and posterior tributary of renal vein might be seen entering posterior to pelvis in some cases (Sinnatamby et al., 2006; Standring et al., 2005).

During routine dissection of undergraduate students, it has been observed over the years that the arrangement of structures at the hilum shows frequent variations. Various case reports have been published (Gesase, 2007; Gupta et al., 2007; Rao et al., 2006; Sampaio \& Favorito, 1991; Hazırolan et al., 2011) reporting variation in arrangement of structures at the hilum. A review of literature however suggested that no systematic study has been carried out documenting the normal and variant anatomy of hilar structures.

\section{MATERIAL AND METHOD}

The present study was undertaken to observe the arrangement of structures in prehilar and hilar regions. One hundred (51 Right and 49 left) embalmed cadaveric kidneys from the collection of department of anatomy were utilized 
for the present study. Hilar dissection was carried out to observe the arrangement of structures entering or leaving the hilum of the kidney. Antero-posterior relations of the structures within one inch of the hilum were recorded.

The arrangement of renal artery, renal vein and the pelvis, antero-posteriorly exhibited great variation in their relation at the hilum. In majority of the cases $(81 \%)$ renal artery divided into anterior and posterior divisions within one inch of the hilum. In $31 \%$ cases anterior trunk of renal artery is the most anteriorly placed structure at the renal hilum. In about $50 \%$ cases retro pelvic structures are observed at the hilum. Similarly, in $22 \%$ of cases a retropelvic tributary of renal vein was observed. Various patterns observed were classified into five types as shown in Fig. 1.

Pattern 1 seen in 27 kidneys (19 right; 8 left), which was subdivided into 2 types (Fig. 2). Pattern 1A seen in 19 kidneys (14 right; 5 left):- Renal vein -- Renal artery -- Pelvis. Pattern 1B seen in 8 kidneys (5 right; 3 left):- Renal vein - Anterior division of renal artery - Posterior division of renal artery - Pelvis.

Anterior

\begin{tabular}{|c|c|c|c|cc|}
\hline \multicolumn{1}{|c|}{ 1A } & 1B & \multicolumn{1}{c|}{ AT } & RV & AD \\
RV & RV & AD & AD & AD & RV \\
RA & AD & RV & P & P & PD \\
P & PD & PD & PT & PD & (8\%) \\
$(19 \%)$ & P & P & PD & $(20 \%)$ & Pattern 5 \\
\hline
\end{tabular}

Posterior

Fig. 1. shows arrangement of structures at renal hilum in five patterns in decreasing frequency. Pattern 1 is further subdivided into 1A and 1B (RV- Renal vein, RA- Renal artery, P- Pelvis, AD- Anterior division of renal artery, PDPosterior division of renal artery, AT- Anterior tributary of renal vein, PT- Posterior tributary of renal vein).
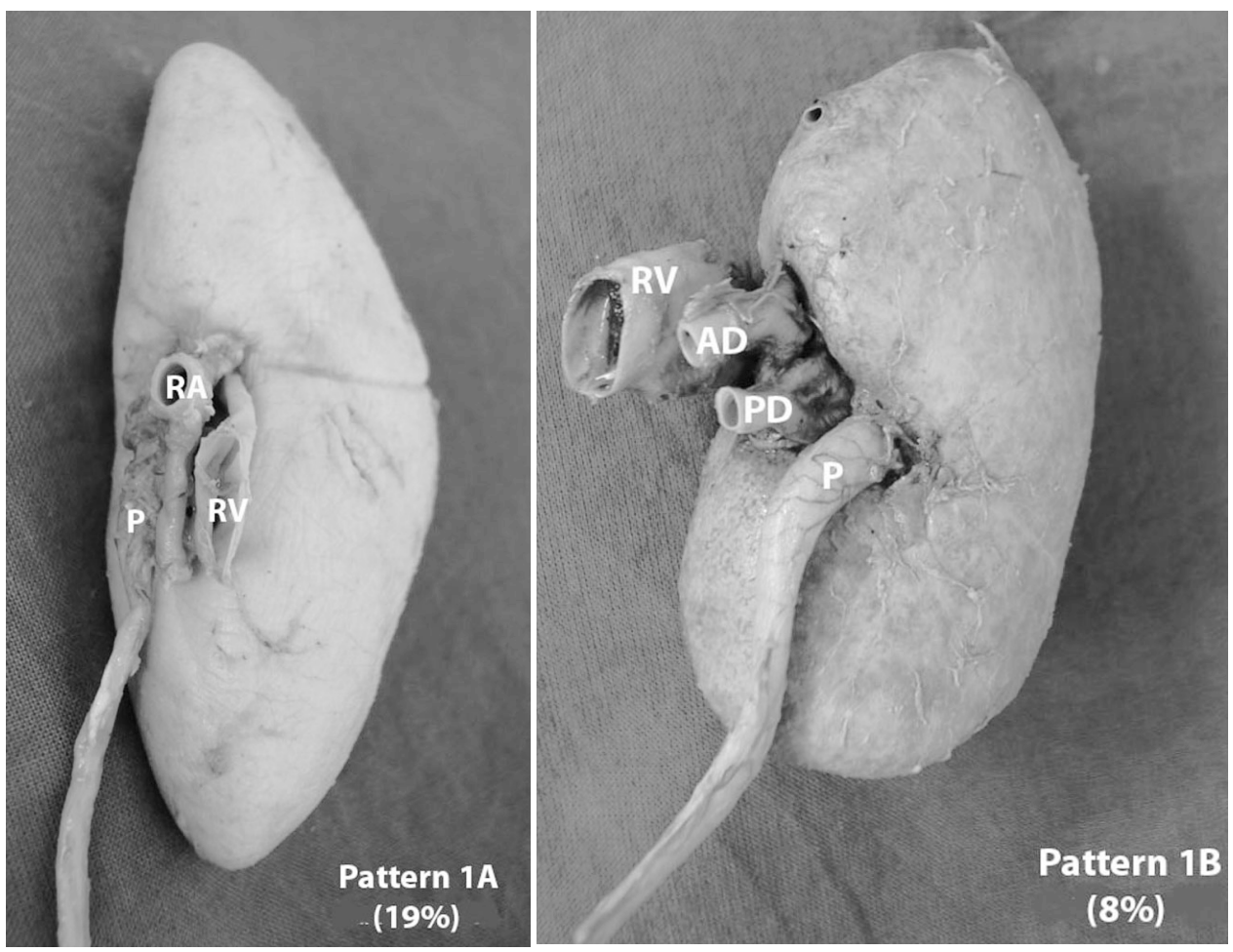

Fig. 2. shows Pattern $1 \mathrm{~A}$ arrangement (left kidney seen from anteromedial aspect) having renal artery between renal vein and pelvis. Pattern $1 \mathrm{~B}$ arrangement (right kidney seen from posteromedial aspect) shows variant of Pattern of $1 \mathrm{~A}$ where anterior and posterior divisions of renal artery lie between renal vein and pelvis (RV- Renal vein, RA- Renal artery, PPelvis, AD- Anterior division of renal artery, PD- Posterior division of renal artery). 
Pattern 2 seen in 23 kidneys (6 right; left 17):- Anterior division of renal artery -- Renal vein -- Posterior division of renal artery -- Pelvis (Fig. 3).

Pattern 3 seen in 22 kidneys (12 right; 10 left):- Anterior tributary of renal vein -- Anterior division of renal artery -- Pelvis -- Posterior tributary of renal vein -- Posterior division of renal artery (Fig. 3).
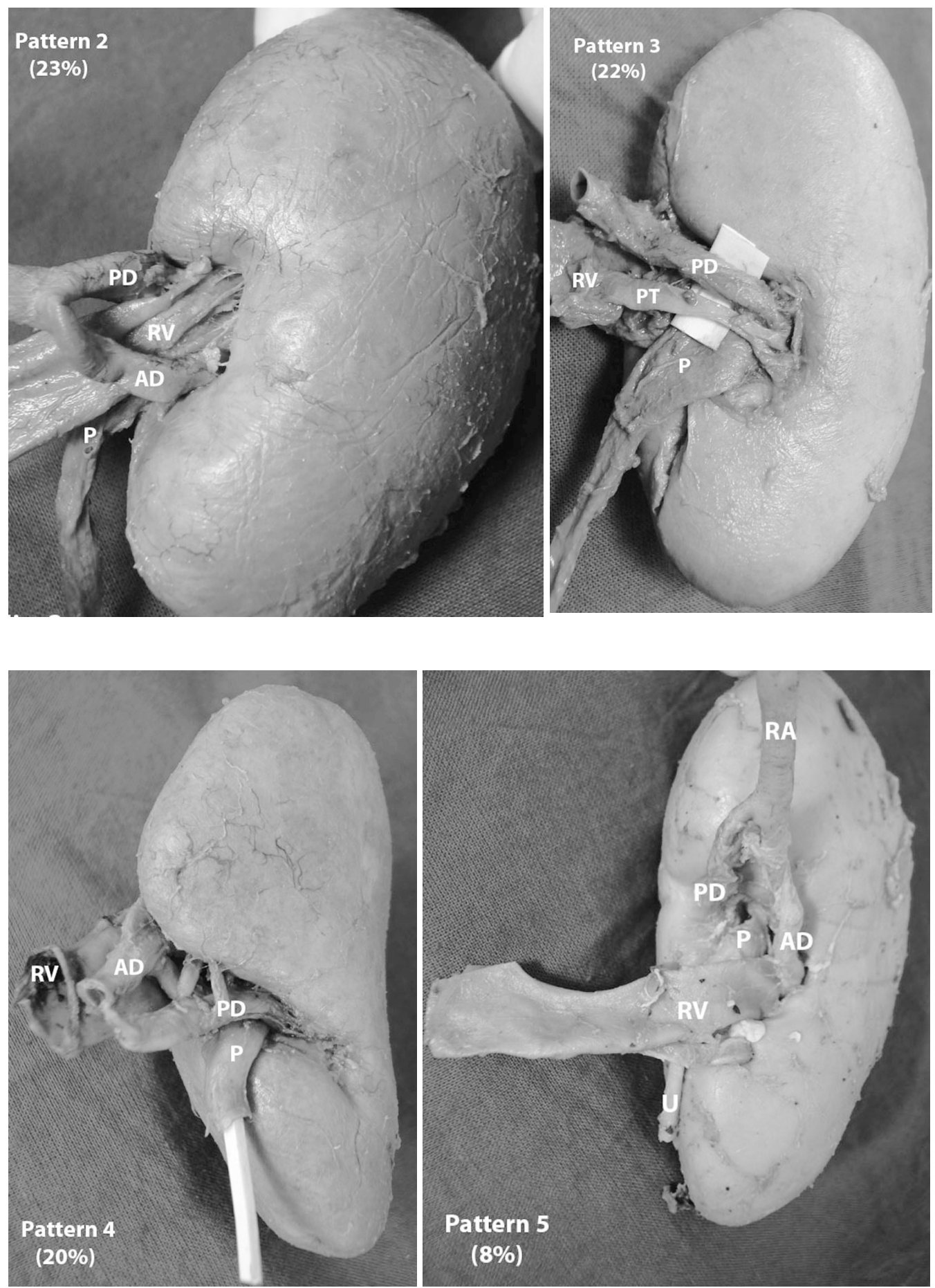

Fig. 4. shows pattern 4 and 5. In pattern 4 (right kidney seen from posterior aspect) pelvis is seen between anterior and posterior division of renal artery while renal vein seen as anterior most relation. In pattern 5 (left kidney seen from anteromedial aspect) renal vein and pelvis were seen between the anterior and posterior divisions of renal artery (RV- Renal vein, ADAnterior division of renal artery, PD- Posterior division of renal artery, P- Pelvis, RA- Renal artery, U- Ureter). 


\section{DISCUSSION}

Anatomical variants of renal hilar structures, as described in the present study, have not received much attention in standard texts of anatomy. A thorough review of literature also failed to yield any such comparable study. Present study demonstrates that structures at the renal hilum show variable arrangements. The pattern $1 \mathrm{~A}$ described in the present study conforms to the description of normal anatomy of standard texts, whereas, Pattern 1B, 2, 3, 4 and 5 are variant patterns. Variant patterns were more commonly observed on the left side. This might be because, embryologically left renal vein is a composite structure derived from multiple anastomotic channels, whereas, the right renal vein is derived from a single anastomotic channel. Deviant development of these channels may change interrelationship of renal hilar structures with respect to renal vein.

This knowledge assumes importance as nephron sparing surgeries like partial nephrectomy by laparoscopic approach have become treatment of choice. Such surgical interventions require hilar dissections which are technically more challenging in laparoscopic approach as compared to open surgeries (Gill et al., 2005; Latouff et al., 2008; Rogers et al.). Dissection of renal vessels and separate clamping of artery, vein and pelvis is preferred over en-bloc mass stapling of renal hilum. En-bloc clamping may result in arteriovenous fistula as a late complication of nephrectomy. A difficult hilar dissection results in conversion of laparoscopic operation to an open procedure (Rapp et al.).

The present study has demonstrated that in majority of cases branches and tributaries of renal vessels occupy the prehilar and hilar region rather than the main trunks of renal vessels. This observation is supported by series of communications by Sampaio et al. They studied vascular relationship of uretropelvic junction and concluded that in the majority of cases a branch of renal artery and/or venous tributaries lies in close proximity of the pelvis implying prehilar branching of renal artery (Sampaio, 1996, 1998; Sampaio \& Aragão, 1990; Sampaio \& Favorito, 1991).

In conclusions (i) In approximately three fourth cases the arrangement of hilar structures does not conform to the normal description (i.e. vein, artery and pelvis); (ii) Variant patterns are more commonly seen on left side; (iii) In approximately one third cases, anterior trunk of renal artery is the most anteriorly placed structure at the renal hilum and (iv) In about $50 \%$ cases retro pelvic structures are observed at the hilum.

TRIVEDI, S.; ATHAVALE, S. \& KOTGIRIWAR, S. Anatomía normal y variante de las estructuras hiliares renales y su significancia clínica. Int. J. Morphol., 29(4):1379-1383, 2011.

RESUMEN: Las técnicas avanzadas de imagen han permitido aumentar el uso de abordajes mínimamente invasivos para la cirugía conservadora del nefrón. Por esto, se justifica la necesidad de un conocimiento preciso de la anatomía normal y las variaciones anatómicas del pedículo vascular del riñón. Es amplia la literatura disponible sobre variaciones en el patrón vascular intrarrenal, lo que se observa con frecuencia. Sin embargo, hasta ahora, la variación en la disposición de las estructuras en el hilio renal no ha generado mucho interés. Se utilizaron 100 riñones fijados (51 derechos y 49 izquierdos) para el estudio. Una cuidadosa disección de las estructuras hiliares renales se llevó a cabo para observar la relación antero-posterior de las estructuras en el hilio del riñón. En la mayoría de los casos (73\%), las características no estaba de acuerdo con la descripción normal de la vena renal, es decir, con la arteria renal y la pelvis renal dispuestos en sentido anteroposterior. Los patrones de las variables observadas fueron clasificadas en cinco tipos. En el $31 \%$ de los casos la división anterior de la arteria renal estaba anterior a la vena renal en el hilio, mientras que, en el 50\% de los casos, la pelvis no estaba posterior. En los casos de tumores renales hiliares la nefrectomía parcial laparoscópica se realiza con un limitado campo de visión. El conocimiento de estas variaciones es útil para un adecuado desempeño de los cirujanos al identificar y separar individualmente las estructuras hiliares, que es una ventaja sobre la separación en bloque.

PALABRAS CLAVE: Riñón; Nefrectomía parcial laparoscópica; Hilio renal; Variaciones.

\section{REFERENCES}

Desai, M. M. \& Gill, I. S. Laparoscopic partial nephrectomy for tumour: current status at the Cleveland Clinic. BJU Int., 95(2):41-5, 2005.

Gesase, A. P. Rare origin of supernumerary renal vessels supplying the lower pole of the kidney. Ann. Anat., 189(1):53-8, 2007.
Gill, I. S.; Colombo, J. R. Jr.; Frank, I.; Moinzadeh, A.; Kaouk, J. \& Desai, M. Laparoscopic partial nephrectomy for hilar tumors. J. Urol., 174(3):850-4, 2005.

Gupta, M.; Pandey, A. K. \& Goyal, N. Horseshoe kidney--a case report. Nepal Med. Coll. J., 9(1):63-6, 2007. 
Hazırolan, T.; Öz, M.; Türkbey, B.; Karaosmanog`lu, A. D.; Og־uz, B. S. \& Canyig it, M. CT angiography of the renal arteries and veins: normal anatomy and variants. Diagn. Interv. Radiol., 17(1):67-73, 2011.

Huang, W. C.; Levey, A. S.; Serio, A. M.; Snyder, M.; Vickers, A. J.; Raj, G. V.; Scardino, P. T. \& Russo, P. Chronic kidney disease after nephrectomy in patients with renal cortical tumours: a retrospective cohort study. Lancet Oncol., 7(9):735-40, 2006.

Lattouf, J. B.; Beri, A.; D'Ambros, O. F.; Grüll, M.; Leeb, K. \& Janetschek, G. Laparoscopic partial nephrectomy for hilar tumors: technique and results. Eur. Urol., 54(2):409-16, 2008.

Nguyen, M. M.; Gill, I. S. \& Ellison, L. M. The evolving presentation of renal carcinoma in the United States: trends from the Surveillance, Epidemiology, and End Results program. J. Urol., $176(6$ Pt1):2397-400, 2006.

Rao, M.; Bhat, S. M.; Venkataramana, V.; Deepthinath, R. \& Bolla, S. R. Bilateral prehilar multiple branching of renal arteries: a case report and literature review. Kadmandu Univ. Med. J., 4(3):345-8, 2006.

Rapp, D. E.; Orvieto, M. A.; Gerber, G. S.; Johnston, W. K. 3rd.; Wolf, J. S. Jr. \& Shalhav, A. L. En bloc stapling of renal hilum during laparoscopic nephrectomy and nephroureterectomy. Urology, 64(4):655-9, 2004.

Rogers, C. G.; Metwalli, A.; Blatt, A. M.; Bratslavsky, G.; Menon, M.; Linehan, W. M. \& Pinto, P. A. Robotic partial nephrectomy for renal hilar tumors: a multi-institutional analysis. J. Urol., 180(6):2353-6, 2008.

Sampaio, F. J. The dilemma of crossing vessels at the ureteropelvic junction: precise anatomic study. J. Endourol., 10(5):411-5, 1996.

Sampaio, F. J. Vascular anatomy at the ureteropelvic junction. Urol. Clin. North Am., 25(2):251-8, 1998.

Sampaio, F. J. \& Aragão, A. H. Anatomical relationship between the renal venous arrangement and the kidney collecting system. J. Urol., 144(5):1089-93, 1990.

Sampaio, F.J. \& Favorito, L. A. Endopyelotomy. Anatomical study of the vascular relationships to ureteropelvic junction. J. Urol., 97(2):73-7, 1991.

Sinnatamby, C. S. Last's anatomy: regional and applied in abdomen. $11^{\text {th }}$ edition. London, Elsevier - Churchill Livingstone, 2006.

Standring, S. Gray's anatomy: the anatomical basis of clinical practice in urinary system. $39^{\text {th }}$ edition. London, Elsevier Churchill Livingstone, 2005.

\author{
Correspondence to: \\ Dr. Soumitra Trivedi \\ Assistant professor \\ Department of Anatomy \\ P. C. M. S. \& R. C. \\ Bhopal, M. P. \\ INDIA
}

Email:dr.somit@gmail.com

Received: 16-03-2011

Accepted: 13-06-2011 